\title{
Influenza A Viruses in Whistling Ducks (Subfamily Dendrocygninae)
}

\author{
Deborah L. Carter ${ }^{1}$, Paul Link ${ }^{2}$, Gene Tan ${ }^{3,4}$, David E. Stallknecht ${ }^{1}$ and Rebecca L. Poulson ${ }^{1, *(D)}$ \\ 1 Southeastern Cooperative Wildlife Disease Study, Department of Population Health, \\ College of Veterinary Medicine, The University of Georgia, 589 D. W. Brooks Dr., Athens, GA 30602, USA; \\ dlcarter@uga.edu (D.L.C.); dstall@uga.edu (D.E.S.) \\ 2 Louisiana Department of Wildlife and Fisheries, 2000 Quail Drive, Room 436, Baton Rouge, LA 70808, USA; \\ plink@wlf.la.gov \\ 3 J. Craig Venter Institute, 4120 Capricorn Lane, La Jolla, CA 92037, USA; gtan@jcvi.org \\ 4 Division of Infectious Diseases, Department of Medicine, University of California, \\ La Jolla, San Diego, CA 92037, USA \\ * Correspondence: rpoulson@uga.edu
}

check for

updates

Citation: Carter, D.L.; Link, P.; Tan, G.; Stallknecht, D.E.; Poulson, R.L. Influenza A Viruses in Whistling Ducks (Subfamily Dendrocygninae). Viruses 2021, 13, 192. https://doi.org/ $10.3390 / v 13020192$

Academic Editor: Ignacio Nacho Mena Received: 31 December 2020

Accepted: 27 January 2021

Published: 28 January 2021

Publisher's Note: MDPI stays neutral with regard to jurisdictional claims in published maps and institutional affiliations.

Copyright: (c) 2021 by the authors. Licensee MDPI, Basel, Switzerland. This article is an open access article distributed under the terms and conditions of the Creative Commons Attribution (CC BY) license (https:/ / creativecommons.org/licenses/by/ $4.0 /$ )

\begin{abstract}
As compared to other Anseriformes, data related to influenza A virus (IAV) detection and isolation, and IAV antibody detection in whistling ducks (Dendrocygna spp. and Thalassornis leuconotus; subfamily Dendrocygninae) are limited. To better evaluate the potential role of whistling ducks in the epidemiology of IAV, we (1) conducted surveillance for IAV from black-bellied whistling ducks (BBWD, Dendrocygna autumnalis) sampled in coastal Louisiana, USA, during February 2018 and 2019, and (2) reviewed the published literature and Influenza Resource Database (IRD) that reported results of IAV surveillance of whistling ducks. In the prospective study, from 166 BBWD sampled, one H10N7 IAV was isolated ( $0.6 \%$ prevalence), and overall blocking enzyme-linked immunosorbent assay (bELISA) antibody seroprevalence was $10 \%$. The literature review included publications and data in the IRD from 1984 to 2020 that reported results from nearly 5000 collected samples. For any given collection, the IAV isolation rate never exceeded $5.5 \%$, and seroprevalence estimates ranged from 0 to $42 \%$. Results from our prospective study in Louisiana are consistent with this historic literature; however, although all data consistently demonstrated a low prevalence of infection, the potential role of this species in the epidemiology of IAV should not be totally discounted. In sum, whistling ducks can be infected with IAV, they represent important species on many areas where waterfowl winter, and their distribution across the globe appears to be changing.
\end{abstract}

Keywords: avian influenza; Dendrocygninae; host; IAV; prevalence; surveillance; whistling ducks

\section{Introduction}

Wild waterfowl in Order Anseriformes are important natural reservoirs for influenza A virus (IAV), but there have been limited reports of IAV in species of whistling ducks (WD; Family Anatidae, Subfamily Dendrocygninae). One of the eight currently recognized species of WD, the black-bellied whistling duck (BBWD; Dendrocygna autumnalis) is common in the Americas. BBWD breed throughout Louisiana, Texas, Mexico, and Central and South-central America, and form large flocks when not breeding, often in association with fulvous whistling ducks (FUWD; Dendrocygna bicolor) [1]. BBWD are largely residential apart from local movement, and tropical populations of BBWD are migratory with movement in the winter months [1]. The distribution of the species is expanding, and BBWD are now abundant along the southeastern coast of the United States [2]. Nocturnal feeders, BBWD forage on seeds, aquatic invertebrates, and vegetation in shallow freshwater [3].

In addition to the BBWD and FUWD, six other WD species are recognized worldwide in genus Dendrocygna, including Dendrocygna arborea (West Indian WD); Dendrocygna arcuata (wandering WD), Dendrocygna eytoni (plumed WD), Dendrocygna guttata (spotted WD), 
Dendrocygna javanica (lesser WD; LEWD), and Dendrocygna viduata (white-faced WD; WFWD); the white-backed duck (Thalassornis leuconatus) is also classified in the Dendrocygninae subfamily. Broadly, WD primarily exhibit only localized movements within their breeding ranges, with some exceptions. Small populations of LEWD in Asia have been noted to leave their northernmost breeding areas in the winter [4], and the globally widespread FUWD are migratory only in the most northern portions of their Mexican range [5].

Though infrequently sampled as compared to some other species in Order Anseriformes, exposure to and infection of IAV has been detected in resident and migrating Dendrocygninae, mostly outside of the United States. To better understand the role of WD in the ecology of IAV, we (1) conducted IAV surveillance of wintering BBWD along the Gulf coast of the United States over two years, and (2) reviewed published literature and the Influenza Resource Database (IRD) [6] for results from worldwide surveillance for IAV in this avian subfamily.

\section{Materials and Methods}

\subsection{Virus Isolation and Antibody Detection}

Cloacal and oropharyngeal (COP) swabs and serum were opportunistically collected from live-captured BBWD in the Louisiana coastal parishes of Vermilion and Jefferson in February 2018 and 2019, respectively (Figure 1). In each year, approximately $40 \%$ of the sampled birds were after hatch year (AHY).

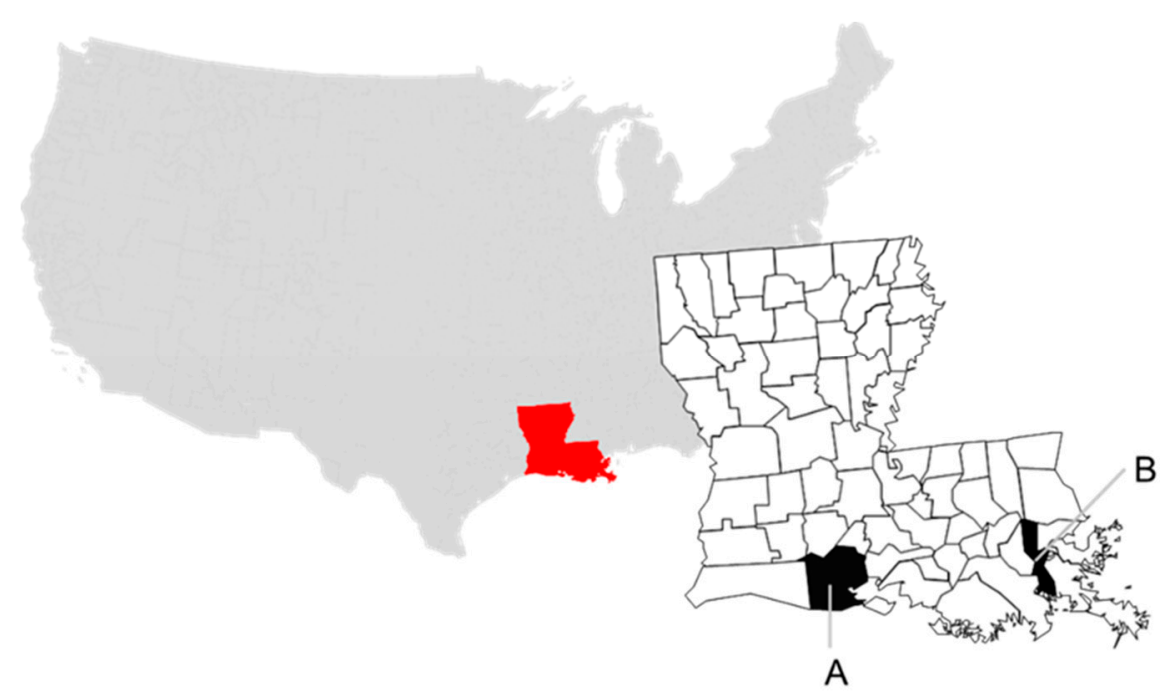

Figure 1. Collection sites in Louisiana, USA at parish level and by sampling year for this study: (A) Vermilion, 2018, and (B) Jefferson, 2019.

Collection sites included rice fields (2018) and a cargo ship terminal situated on the Mississippi River, where thousands of BBWD and other waterfowl were observed (personal observation, Paul Link, 2019). Virus isolation (VI) was performed on COP swabs as previously described [7]. Viral RNA was extracted (QIAamp Viral RNA Mini Kit, Qiagen Inc., Valencia, CA, USA) from all VI-positive samples following the manufacturer's recommendation, and tested by IAV matrix real-time reverse transcriptase PCR (RRTPCR) [8]. Whole-genome sequencing of IAV-positive isolates was carried out at J. Craig Venter Institute. Phylogenetic analyses were conducted using MEGA version 6 [9]; the top 2 NCBI basic local alignment search tool (BLAST) results, based on percent nucleotide (nt) similarity, were chosen on the basis of the criteria that they were from viruses identified from avian species at times predating the query sequence. Sterile blood samples were collected at a total volume less than or equal to $1 \%$ of the bird body mass via the brachial wing vein. Serum fractions were tested by nucleoprotein (NP) blocking enzyme-linked immunosorbent assay (bELISA; IDEXX, Westbrooke, ME, USA); samples with S/N ratios 
$<0.7$ were considered seropositive $[10,11]$. Animal work was approved by UGA Institutional Animal Care and Use Committee approval A2016 05-020-Y3-A6.

\subsection{Literature Review}

We searched over 3 decades (1984-2020) worth of publications on IAV surveillance in wild birds in subfamily Dendrocygninae: D. arcuata, D. autumnalis, D. bicolor, D. eytoni, D. javanica, D. viduata, and T. leuconatus. Prevalence data and metadata, including sampling country, species, sampling season, and year, and testing method(s) were extracted from each publication as available. Google Scholar (http:/ /scholar.google.com) and PubMed (www.ncbi.nlm.nih.gov/pubmed, accessed on 1 September 2020) were searched from 1 September 2020 to 8 September 2020. Data were also obtained from the National Institute of Allergy and Infectious Diseases (NIAID) Influenza Research Database (IRD) [6] through the website of http:/ / www.fludb.org, accessed on 15 October 2020; every attempt was made to assure that results reported from this outlet are not in publication elsewhere.

\section{Results}

\subsection{Prospective-Virus Isolation and Antibody Detection}

In total, 92 (2018) and 74 (2019) BBWD COP swab and serum samples were tested by both VI and NP bELISA. One H10N7 IAV was isolated in 2018 (A/black-bellied whistling duck/Louisiana/UGAI18-484/2018); no viruses were isolated in 2019. The gene sequences of the $\mathrm{H} 10$ hemagglutinin and N7 neuraminidase surface glycoproteins were most closely related to those of A/mallard/Ohio/16OS0620/2016 (H10N7) (Table 1). All internal genes were closely related to recently identified North American wild waterfowl sequences (Table 1). Three serum samples were NP bELISA-positive in 2018 (3.3\% seroprevalence), and 14 in 2019 (18.9\% seroprevalence), suggesting previous exposure to avian IAV. Seroprevalence in AHY birds across both years was 12.5\% compared to $9.7 \%$ in hatch year (HY) birds.

Table 1. Comparison of the eight influenza A virus (IAV) gene sequences for the virus isolated in this study (A/black-bellied whistling duck/Louisiana/UGAI18-484 (H10N7)) with avian IAV available on Genbank that have the highest nucleotide (nt) similarity. Results were obtained on 11 June 2020 using the NCBI basic local alignment search tool (BLAST) function; the top two BLAST results are listed.

\begin{tabular}{|c|c|c|c|c|}
\hline $\begin{array}{c}\text { A/BBWD/LA/UGAI18- } \\
484 \text { (H10N7) } \\
\text { Genbank Accession } \\
\text { No. (Gene Segment) }\end{array}$ & & BLAST Result & $\begin{array}{c}\text { GenBank } \\
\text { Accession No. }\end{array}$ & $\begin{array}{c}\% \text { nt } \\
\text { Similarity }\end{array}$ \\
\hline \multirow{2}{*}{ MN937687 (PB2) } & First & A/MALL/IL/16OS4580/2016(H7N3) & MG279778 & 99.2 \\
\hline & Second & A/MALL/OH/17OS1892/2017(H10N7) & MK236922 & 99.1 \\
\hline \multirow{2}{*}{ MN937686 (PB1) } & First & A/MALL/OH/16OS0620/2016(H10N7) & KY561093 & 99.4 \\
\hline & Second & A/COGO/WI/16OS4147/2016(H10N3) & MG280078 & 99.2 \\
\hline \multirow{2}{*}{ MN937685 (PA) } & First & A/BWTE/WY/AH0099021/2016(H7N9) & MG266063 & 99.5 \\
\hline & Second & A/duck/AL/17-008643-2/2017(H7N9) & MF357835 & 99.5 \\
\hline \multirow{2}{*}{ MN937680 (HA) } & First & A/MALL/OH/16OS0620/2016(H10N7) & KY561022 & 99.4 \\
\hline & Second & A/NSHO/NV/D1615770/2016(H10N9) & MK928244 & 99.1 \\
\hline \multirow{2}{*}{ MN937683 (NP) } & First & A/GWTE/IL/17OS1400/2017(H7N3) & MG279995 & 99.5 \\
\hline & Second & A/MALL/OH/17OS1739/2017(H3N8 & MK237096 & 99.4 \\
\hline \multirow{2}{*}{ MN937682 (NA) } & First & A/MALL/OH/16OS0620/2016(H10N7) & KY561241 & 99.5 \\
\hline & Second & A/MALL/IL/16OS4899/2016(H10N7) & MG279737 & 99.3 \\
\hline \multirow{2}{*}{ MN937681 (M) } & First & A/LESC/IL/17OS1577/2017(H7N3) & MG280109 & 99.4 \\
\hline & Second & A/NSHO/IL/11OS5680/2011(H11N9) & CY166988 & 98.9 \\
\hline \multirow{2}{*}{ MN937684 (NS) } & First & A/NSHO/CA/HS206/2015(H8N4) & KY983106 & 99.3 \\
\hline & Second & A/BWTE/Guatemala/CIP049H102-18/2011(H1N3) & KX960456 & 99.3 \\
\hline
\end{tabular}

Abbreviations were used in strain names for host species (BBWD = black-bellied whistling duck; BWTE = blue-winged teal; COGO = common goldeneye; GWTE = green-winged teal; LESC = lesser scaup; MALL = mallard; NSHO = Northern shoveler) and sample locations $(\mathrm{AL}=$ Alabama; $\mathrm{CA}=$ California; $\mathrm{IL}=$ Illinois; $\mathrm{LA}=$ Louisiana; $\mathrm{MN}=$ Minnesota; $\mathrm{NV}=\mathrm{Nevada}$; $\mathrm{OH}=\mathrm{Ohio}$; $\mathrm{WI}=\mathrm{Wisconsin}$; $\mathrm{WY}=$ Wyoming). 


\subsection{Retrospective—Literature Review}

As compared to some anatids, especially several Anas and Anser species, IAV surveillance has been fairly limited in Dendrocygninae, and often is the result of opportunistic sampling. Results of virus isolation (4942 samples) and/or PCR (4837 samples) testing were reported in 18 publications and include collection efforts of WD in Africa, Asia, Australia, and North and South America (Table 2). The overall PCR positivity rate was 1.7\% (0-100\% range), and the overall mean prevalence based on virus isolation was $0.1 \%(0-5.6 \%$, range $)$. In western Africa, 38 of 1269 (3.0\%) whistling ducks tested IAV matrix-positive by PCR [12]. Cumming et al. [13] surveyed 165 avian species in southern Africa; IAV prevalence was $5.2 \%$ for birds in subfamily Dendrocygninae, twice as high as that reported from other ducks in the same study. In west Africa, highly pathogenic H5 genomes were identified in apparently healthy WFWD [14]. In the Americas, only three species of whistling ducks are known: BBWD, FUWD, and WFWD. Although infrequently sampled, IAV has been detected in each of these species. Influenza A viral RNA was detected in 14/489 (2.9\%) BBWD and 5/71 (7.0\%) WFWD in Colombia [15], and low pathogenicity H5N2 viruses were isolated from each of these hosts. In Texas, IAV was detected in 2/18 overwintering FUWD, resulting in the isolation of an H6N1 subtype IAV [16]. Five publications reported serological results from WD. Primarily on the basis of ELISA testing, we found that seroprevalence ranged from 0 to $42 \%$ (Table 3 ). 


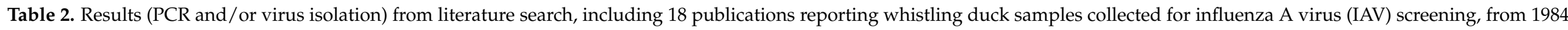
to 2020. Yellow highlighted rows indicate the detection of highly pathogenic (HP) IAV.

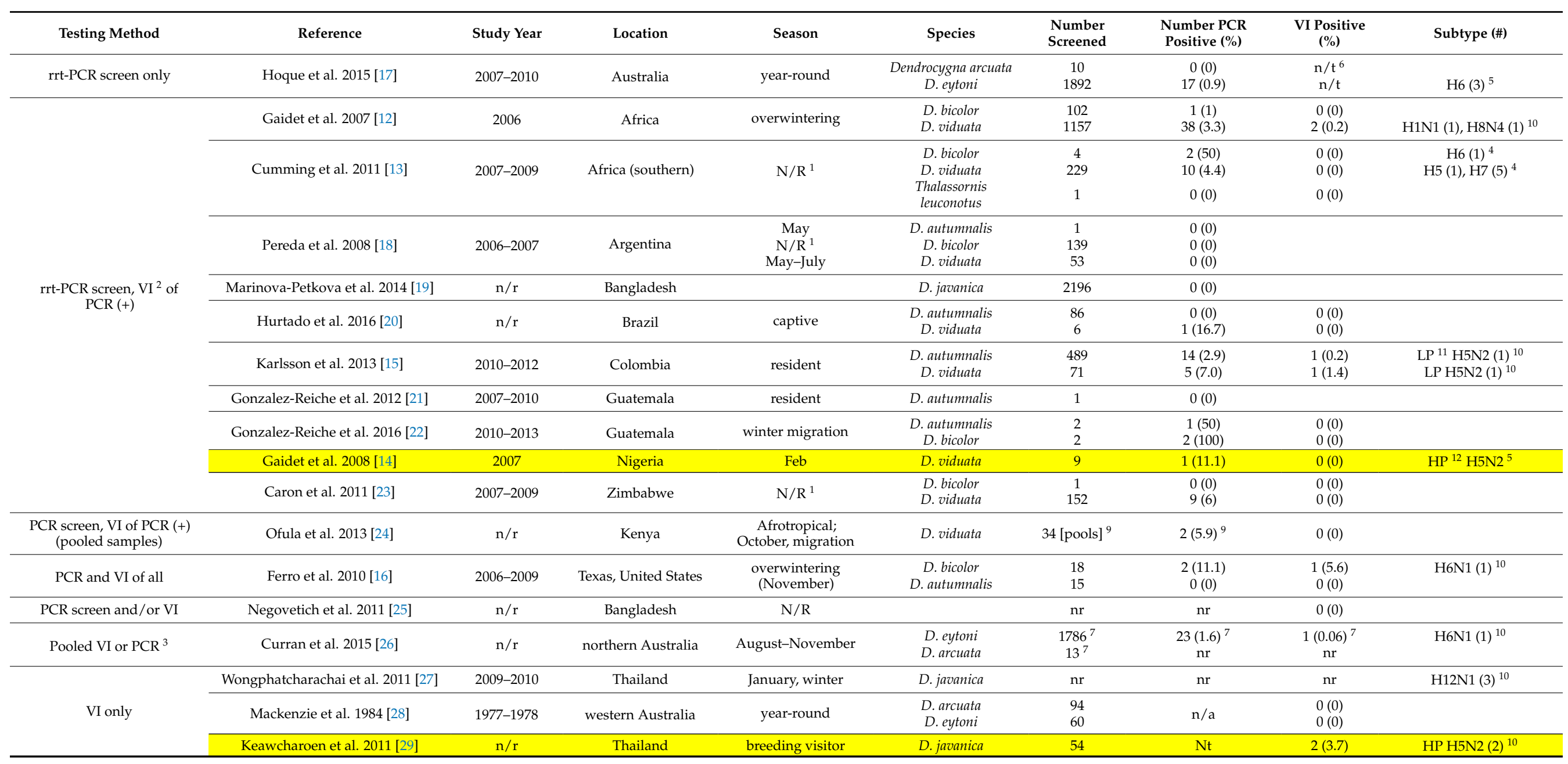


Table 2. Cont

\begin{tabular}{|c|c|c|c|c|c|c|c|c|c|}
\hline Testing Method & Reference & Study Year & Location & Season & Species & $\begin{array}{l}\text { Number } \\
\text { Screened }\end{array}$ & $\begin{array}{l}\text { Number PCR } \\
\text { Positive (\%) }\end{array}$ & $\begin{array}{l}\text { VI Positive } \\
(\%)\end{array}$ & Subtype (\#) \\
\hline & & & & & $\begin{array}{l}\text { PCR totals }{ }^{8} \\
\text { VI Results }\end{array}$ & $\begin{array}{l}4837 \\
4942\end{array}$ & $\begin{array}{c}84 \\
7\end{array}$ & $\begin{array}{l}1.7 \% \\
0.1 \%\end{array}$ & \\
\hline
\end{tabular}

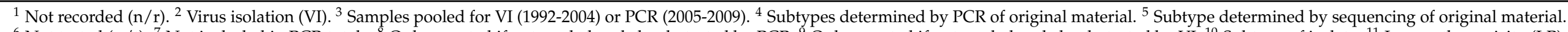

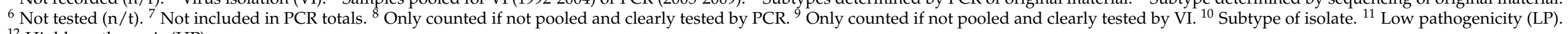

${ }^{12}$ Highly pathogenic (HP).

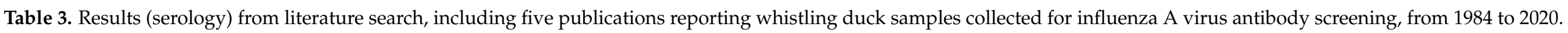

\begin{tabular}{|c|c|c|c|c|c|c|c|}
\hline Testing Method & Reference & Location & Season & Species & $\begin{array}{l}\text { Number } \\
\text { Screened }\end{array}$ & $\begin{array}{c}\text { Initial Screen } \\
\text { (\% Positive) }\end{array}$ & $\begin{array}{c}\text { Second Screen } \\
\text { (\% Positive) }\end{array}$ \\
\hline \multirow{2}{*}{$\begin{array}{c}\text { cELISA }^{\mathrm{a}} \text { screen, } \mathrm{HI}^{\mathrm{b}} \text { of } \\
\text { ELISA }(+)\end{array}$} & \multirow{2}{*}{ Hoque et al. 2015 [17] } & \multirow{2}{*}{ Australia } & \multirow{2}{*}{ year-round } & Dendrocygna arcuata & 8 & $1(12.5)$ & $\mathrm{n} / \mathrm{r}$ \\
\hline & & & & D. eytoni & 1209 & $90(7.4)$ & $\mathrm{n} / \mathrm{r}$ \\
\hline \multirow{5}{*}{ AGID $^{c}$ and bELISA ${ }^{d}$} & \multirow{5}{*}{ Brown et al. 2010 [30] } & \multirow{5}{*}{ Argentina } & May & D. autumnalis & 1 & $0(0)$ & $0(0)$ \\
\hline & & & unknown & & 45 & $1(2.0)$ & $12(27.0)$ \\
\hline & & & January-February & D. bicolor & 14 & $1(7.1)$ & $5(35.7)$ \\
\hline & & & May-July & & 31 & $0(0)$ & $7(22.3)$ \\
\hline & & & May-July & D. viduata & 9 & $0(0)$ & $0(0)$ \\
\hline \multirow{3}{*}{ cELISA screen, HI } & \multirow{2}{*}{ Curran et al. 2015 [26] } & \multirow{2}{*}{ northern Australia } & \multirow{2}{*}{ August-November } & D. arcuata & 11 & $1(9.1)$ & $\mathrm{n} / \mathrm{r}$ \\
\hline & & & & D. eytoni & 1806 & $757(41.9)$ & $\mathrm{n} / \mathrm{r}$ \\
\hline & Hassan et al. 2020 [31] & Bangladesh & migratory; winter & D. javanica & $\mathrm{n} / \mathrm{r}^{\mathrm{e}}$ & 5 & $\mathrm{n} / \mathrm{r}$ \\
\hline \multirow[t]{2}{*}{ ELISA } & Daodu et al. 2020 [32] & Nigeria & unknown & D. viduata & 4 & $0(0)$ & $\mathrm{n} / \mathrm{a}^{\mathrm{f}}$ \\
\hline & & & & Total screened & 3130 & $851(27)$ & \\
\hline
\end{tabular}

${ }^{a}$ Competitive enzyme-linked immunosorbent assay. ${ }^{b}$ Hemagglutination inhibition (HI). ${ }^{\mathrm{c}}$ Agar gel immunodiffusion (AGID). ${ }^{\mathrm{d}}$ blocking (b)ELISA. ${ }^{\mathrm{e}}$ not reported (n/r). ${ }^{\mathrm{f}}$ not applicable (n/a). 
In addition to the published literature, the IRD included 4248 IAV results for WD sampled from 2007 to 2019 (Table 4). The majority of WD surveillance submissions to IRD $(3655,86 \%)$ were from LEWD sampled on the Asian continent. Of these, $223(6.1 \%)$ were reported as IAV-positive.

Table 4. Results from Influenza Research Database search, not previously included in publications, reporting influenza A virus surveillance data spanning the years 2007-2019 for whistling duck species sampled on five continents.

\begin{tabular}{ccccccc}
\hline \multicolumn{7}{c}{ Continent } \\
\hline Species & Africa & Asia & Australia & North America & South America & Total \\
\hline Dendrocygna autumnalis & $\mathrm{n} / \mathrm{r} 1$ & $\mathrm{n} / \mathrm{r}$ & $\mathrm{n} / \mathrm{r}$ & $0 / 39$ & $0 / 44$ & $0 / 83$ \\
D. bicolor & $0 / 8^{2}$ & $\mathrm{n} / \mathrm{r}$ & $\mathrm{n} / \mathrm{r}$ & $0 / 5$ & $0 / 101$ & $\mathrm{n} / \mathrm{r}$ \\
D. eytoni & $\mathrm{n} / \mathrm{r}$ & $\mathrm{n} / \mathrm{r}$ & $0 / 3$ & $\mathrm{n} / \mathrm{r}$ & $\mathrm{n} / \mathrm{r}$ & $223 / 3655(6.1)$ \\
D. javanica & $\mathrm{n} / \mathrm{r}$ & $223 / 3655(6.1)$ & $\mathrm{n} / \mathrm{r}$ & $\mathrm{n} / \mathrm{r}$ & $0 / 377$ & $0 / 391$ \\
D. viduata & $0 / 14$ & $\mathrm{n} / \mathrm{r}$ & $\mathrm{n} / \mathrm{r}$ & $\mathrm{n} / \mathrm{r}$ & $0 / 2$ & $\mathrm{n} / \mathrm{r}$ \\
Dendrocygna spp. & $\mathrm{n} / \mathrm{r}$ & $0 / 2$ & $\mathrm{n} / \mathrm{r}$ & $0 / 44$ & $0 / 522$ & $223 / 4248(5.2)$ \\
\hline Total & $0 / 22$ & $223 / 3657(6.1)$ & $0 / 3$ & &
\end{tabular}

\section{Discussion}

Results from efforts reported here indicate that BBWD are exposed to (seroprevalence range $3.3 \%-18.9 \%$ ) and can be infected by (isolation of H10N7) avian IAV; the observed prevalence of IAV infection as determined by virus isolation $(0.6 \%)$ was found to be low but consistent with prevalence estimates for other wintering duck species elsewhere in the Americas [7,33-35]. However, the NP antibody prevalence described in this study was substantially lower than that observed in mallard and teal species collected at sites in Louisiana at the same time of year (average 65\%, 2018-2019; unpublished data). Low apparent seroprevalence in these resident WD may represent limited lifetime exposure to IAV due to this species' limited geographic range within waterfowl wintering habitats in North America; this is supported by the low overall seroprevalence in adult (AHY) BBWD in this study (12.5\%, average). Unlike mallard and teal species, WD are not present on traditional waterfowl breeding and staging areas during fall migration where IAV prevalence is consistently at its highest [34]. Disparate behavior and foraging strategies, largely localized movement, single species flocks, and differential susceptibility to IAV may also limit IAV exposure and play a role in the limited detection of antibodies we report in this resident species. Given that the ability of avian hosts to respond to exposure to IAV varies by species [36], differences in the ability of BBWD to mount a measurable immune response, as compared to other anatids, also cannot be discounted.

Travelling in large flocks and globally abundant on many waterfowl wintering areas, species of WD have been shown to be infected with similar IAV as migratory waterfowl. Further, the detection of highly pathogenic avian influenza (HPAI) virus in healthy WFWD in Africa [14] emphasizes the role that WD may have in the distribution and possibly the maintenance of HPAI and other pathogens of concern. Taken together, these results indicate that Dendrocygninae may play a role in the ecology and epidemiology of IAV, but given that they have been understudied in comparison to some anatid species, their potential importance in the natural history of IAV remains unknown. Results here, which are consistent with historic reports, demonstrate a low prevalence of infection in all WD species surveyed. Given that WD can be infected, the fact that they represent important species on many areas where waterfowl winter, and the fact that they have changing distribution in some parts of the world, the potential role of these species in the epidemiology of IAV should not be totally discounted. 
Supplementary Materials: The following are available online at https:/ / www.mdpi.com/1999-491 5/13/2/192/s1, Table S1: Antibody detection (bELISA) and virus isolation results for serum and swab samples collected in this study.

Author Contributions: Conceptualization D.L.C., P.L., D.E.S., and R.L.P.; investigation, D.L.C., P.L., G.T., D.E.S., and R.L.P.; formal analysis, G.T. and R.L.P.; resources, G.T.; writing-original draft preparation, D.L.C., D.E.S., and R.L.P.; writing—review and editing, D.L.C., P.L., G.T., D.E.S., and R.L.P.; funding acquisition, G.T. and D.E.S. All authors have read and agreed to the published version of the manuscript.

Funding: Funding was provided by the CEIRS, National Institute of Allergy and Infectious Diseases (NIAID), National Institutes of Health (NIH), Department of Health and Human Services (HHS), under contract HHSN272201400006C. The Influenza Research Database has been wholly funded with federal funds from NIAID, NIH, and HHS under contract no. 75N93019C00076. This project has also been funded in part with federal funds from the NIAID, NIH, and HHS under award number U19AI110819. The funding agencies were not involved in the design, implementation, or publishing of this study and the research presented herein represents the opinions of the authors, but not necessarily the opinions of the funding agencies.

Institutional Review Board Statement: The study was conducted according to the guidelines of the Declaration of Helsinki and approved by the Institutional Review Board (or Ethics Committee) of the University of Georgia Institutional Animal Care and Use Committee approval A2016 05-020-Y3-A6.

Informed Consent Statement: Not applicable.

Data Availability Statement: The data presented in this study are available in Supplementary Table S1.

Acknowledgments: We thank Alinde Fojtik, Brett Leach, and personnel from the Southeastern Cooperative Wildlife Disease Study and the Louisiana Department of Wildlife and Fisheries for assistance and support of this project. We also thank Torrey Williams, Alan Durbin, Nadia Fedorova, and Paolo Amedeo at J. Craig Venter Institute for their sequencing support.

Conflicts of Interest: The authors declare no conflict of interest. The funders had no role in the design of the study; in the collection, analyses, or interpretation of data; in the writing of the manuscript; or in the decision to publish the results.

\section{References}

1. James, J.; Thompson, J. Black-bellied Whistling-Duck (Dendrocygna autumnalis), version 1.0. In Birds of the World; Poole, A., Gill, F., Eds.; Cornell Lab of Ornithology: Ithaca, NY, USA, 2020.

2. Cohen, B.; Askin, S.; Balkcom, G.; Benedict, R.; Rader, J.; James, J.; Collier, B.; Chamberlain, M. Survival and distribution of Black-bellied Whistling-duck (Dendrocygna autumnalis) in the Southeastern United States. J. Southeast. Assoc. Fish. Wildl. 2019, 6, 123-128.

3. Cain, B.W. Energetics of growth for Black-bellied Tree Ducks. Condor 1976, 78, 124-128. [CrossRef]

4. Carboneras, C.; Kirwan, G.M. Lesser Whistling-Duck (Dendrocygna javanica), version 1.0. In Birds of the World; del Hoyo, J., Elliot, A., Sargatal, J., Christie, D.A., de Jauna, E., Eds.; Cornell Lab of Ornithology: Ithaca, NY, USA, 2020.

5. Hohman, W.L.; Lee, S.A. Fulvous Whistling-Duck (Dendrocygna bicolor), version 1.0. In Birds of the World; Billerman, S.M., Ed.; Cornell Lab of Ornithology: Ithaca, NY, USA, 2020.

6. Zhang, Y.; Aevermann, B.D.; Anderson, T.K.; Burke, D.F.; Dauphin, G.; Gu, Z.; He, S.; Kumar, S.; Larsen, C.N.; Lee, A.J.; et al. Influenza Research Database: An integrated bioinformatics resource for influenza virus research. Nucleic Acids Res. 2017, 45, D466-D474. [CrossRef] [PubMed]

7. Stallknecht, D.E.; Shane, S.M.; Zwank, P.J.; Senne, D.A.; Kearney, M.T. Avian influenza viruses from migratory and resident ducks of coastal Louisiana. Avian Dis. 1990, 34, 398-405. [CrossRef] [PubMed]

8. Spackman, E.; Senne, D.A.; Myers, T.J.; Bulaga, L.L.; Garber, L.P.; Perdue, M.L.; Lohman, K.; Daum, L.T.; Suarez, D.L. Development of a real-time reverse transcriptase PCR assay for type A influenza virus and the avian H5 and H7 hemagglutinin subtypes. J. Clin. Microbiol. 2002, 40, 3256-3260. [CrossRef] [PubMed]

9. Tamura, K.; Stecher, G.; Peterson, D.; Filipski, A.; Kumar, S. MEGA6: Molecular Evolutionary Genetics Analysis version 6.0. Mol. Biol. Evol. 2013, 30, 2725-2729. [CrossRef]

10. Brown, J.D.; Stallknecht, D.E.; Berghaus, R.D.; Luttrell, M.P.; Velek, K.; Kistler, W.; Costa, T.; Yabsley, M.J.; Swayne, D. Evaluation of a commercial blocking enzyme-linked immunosorbent assay to detect avian influenza virus antibodies in multiple experimentally infected avian species. Clin. Vaccine Immunol. 2009, 16, 824-829. [CrossRef] 
11. Shriner, S.A.; VanDalen, K.K.; Root, J.J.; Sullivan, H.J. Evaluation and optimization of a commercial blocking ELISA for detecting antibodies to influenza A virus for research and surveillance of mallards. J. Virol. Methods 2016, 228, 130-134. [CrossRef]

12. Gaidet, N.; Dodman, T.; Caron, A.; Balanca, G.; Desvaux, S.; Goutard, F.; Cattoli, G.; Lamarque, F.; Hagemeijer, W.; Monicat, F. Avian influenza viruses in water birds, Africa. Emerg. Infect. Dis. 2007, 13, 626-629. [CrossRef]

13. Cumming, G.S.; Caron, A.; Abolnik, C.; Cattoli, G.; Bruinzeel, L.W.; Burger, C.E.; Cecchettin, K.; Chiweshe, N.; Mochotlhoane, B.; Mutumi, G.L.; et al. The ecology of influenza A viruses in wild birds in southern Africa. Ecohealth 2011, 8, 4-13. [CrossRef]

14. Gaidet, N.; Cattoli, G.; Hammoumi, S.; Newman, S.H.; Hagemeijer, W.; Takekawa, J.Y.; Cappelle, J.; Dodman, T.; Joannis, T.; Gil, P.; et al. Evidence of infection by H5N2 highly pathogenic avian influenza viruses in healthy wild waterfowl. PLoS Pathog. 2008, 4, e1000127. [CrossRef] [PubMed]

15. Karlsson, E.A.; Ciuoderis, K.; Freiden, P.J.; Seufzer, B.; Jones, J.C.; Johnson, J.; Parra, R.; Gongora, A.; Cardenas, D.; Barajas, D.; et al. Prevalence and characterization of influenza viruses in diverse species in Los Llanos, Colombia. Emerg. Microbes Infect. 2013, 2, e20. [CrossRef] [PubMed]

16. Ferro, P.J.; Budke, C.M.; Peterson, M.J.; Cox, D.; Roltsch, E.; Merendino, T.; Nelson, M.; Lupiani, B. Multiyear surveillance for avian influenza virus in waterfowl from wintering grounds, Texas coast, USA. Emerg. Infect. Dis. 2010, 16, 1224-1230. [CrossRef]

17. Hoque, M.A.; Burgess, G.W.; Cheam, A.L.; Skerratt, L.F. Epidemiology of avian influenza in wild aquatic birds in a biosecurity hotspot, North Queensland, Australia. Prev. Vet. Med. 2015, 118, 169-181. [CrossRef] [PubMed]

18. Pereda, A.J.; Uhart, M.; Perez, A.A.; Zaccagnini, M.E.; La Sala, L.; Decarre, J.; Goijman, A.; Solari, L.; Suarez, R.; Craig, M.I.; et al Avian influenza virus isolated in wild waterfowl in Argentina: Evidence of a potentially unique phylogenetic lineage in South America. Virology 2008, 378, 363-370. [CrossRef] [PubMed]

19. Marinova-Petkova, A.; Feeroz, M.M.; Rabiul Alam, S.M.; Kamrul Hasan, M.; Akhtar, S.; Jones-Engel, L.; Walker, D.; McClenaghan, L.; Rubrum, A.; Franks, J.; et al. Multiple introductions of highly pathogenic avian influenza H5N1 viruses into Bangladesh. Emerg. Microbes Infect. 2014, 3, e11. [CrossRef] [PubMed]

20. Hurtado, R.; de Azevedo-Junior, S.M.; Vanstreels, R.E.; Fabrizio, T.; Walker, D.; Rodrigues, R.C.; Seixas, M.M.; de Araujo, J.; Thomazelli, L.M.; Ometto, T.L.; et al. Surveillance of avian influenza virus in aquatic birds on the Brazilian Amazon Coast. Ecohealth 2016, 13, 813-818. [CrossRef] [PubMed]

21. Gonzalez-Reiche, A.S.; Morales-Betoulle, M.E.; Alvarez, D.; Betoulle, J.L.; Muller, M.L.; Sosa, S.M.; Perez, D.R. Influenza a viruses from wild birds in Guatemala belong to the North American lineage. PLoS ONE 2012, 7, e32873. [CrossRef]

22. Gonzalez-Reiche, A.S.; Muller, M.L.; Ortiz, L.; Cordon-Rosales, C.; Perez, D.R. Prevalence and diversity of low pathogenicity avian influenza viruses in wild birds in Guatemala, 2010-2013. Avian Dis. 2016, 60 (Suppl. 1), 359-364. [CrossRef]

23. Caron, A.; Abolnik, C.; Mundava, J.; Gaidet, N.; Burger, C.E.; Mochotlhoane, B.; Bruinzeel, L.; Chiweshe, N.; de Garine-Wichatitsky, M.; Cumming, G.S. Persistence of low pathogenic avian influenza virus in waterfowl in a Southern African ecosystem. Ecohealth 2011, 8, 109-115. [CrossRef]

24. Ofula, V.O.; Franklin, A.B.; Root, J.J.; Sullivan, H.J.; Gichuki, P.; Makio, A.; Bulimo, W.; Abong'o, B.O.; Muchai, M.; Schnabel, D. Detection of avian influenza viruses in wild waterbirds in the Rift Valley of Kenya using fecal sampling. Vector Borne Zoonotic Dis. 2013, 13, 394-400. [CrossRef] [PubMed]

25. Negovetich, N.J.; Feeroz, M.M.; Jones-Engel, L.; Walker, D.; Alam, S.M.; Hasan, K.; Seiler, P.; Ferguson, A.; Friedman, K.; Barman, S.; et al. Live bird markets of Bangladesh: H9N2 viruses and the near absence of highly pathogenic H5N1 influenza. PLoS ONE 2011, 6, e19311. [CrossRef] [PubMed]

26. Curran, J.M.; Ellis, T.M.; Robertson, I.D. Serological surveillance of wild waterfowl in Northern Australia for avian influenza virus shows variations in prevalence and a cyclical periodicity of infection. Avian Dis. 2015, 59, 492-497. [CrossRef] [PubMed]

27. Wongphatcharachai, M.; Wisedchanwet, T.; Lapkuntod, J.; Nonthabenjawan, N.; Jairak, W.; Amonsin, A. Genetic characterization of influenza A virus subtype H12N1 isolated from a watercock and lesser whistling ducks in Thailand. Arch. Virol. 2012, 157, 1123-1130. [CrossRef]

28. Mackenzie, J.S.; Edwards, E.C.; Holmes, R.M.; Hinshaw, V.S. Isolation of ortho- and paramyxoviruses from wild birds in Western Australia, and the characterization of novel influenza A viruses. Aust. J. Exp. Biol. Med. Sci. 1984, 62 Pt 1, 89-99. [CrossRef]

29. Keawcharoen, J.; van den Broek, J.; Bouma, A.; Tiensin, T.; Osterhaus, A.D.; Heesterbeek, H. Wild birds and increased transmission of highly pathogenic avian influenza (H5N1) among poultry, Thailand. Emerg. Infect. Dis. 2011, 17, 1016-1022. [CrossRef]

30. Brown, J.D.; Luttrell, M.P.; Uhart, M.M.; del Valle Ferreyra, H.; Romano, M.M.; Rago, M.V.; Stallknecht, D.E. Antibodies to type A influenza virus in wild waterbirds from Argentina. J. Wildl. Dis. 2010, 46, 1040-1045. [CrossRef]

31. Hassan, M.M.; El Zowalaty, M.E.; Islam, A.; Khan, S.A.; Rahman, M.K.; Jarhult, J.D.; Hoque, M.A. Prevalence and diversity of avian influenza virus hemagglutinin sero-subtypes in poultry and wild birds in Bangladesh. Vet. Sci. 2020, 7, 73. [CrossRef]

32. Daodu, O.B.; Jegede, H.O.; Aiyedun, J.O.; Oludairo, O.O.; Olorunshola, I.D.; Daodu, O.C.; Ajadi, A.; Ambali, S.F. Surveillance for avian influenza virus in captive wild birds and indigenous chickens in Nigeria. Trop. Anim. Health Prod. 2020, 52, $2387-2393$. [CrossRef]

33. Bowman, A.S.; Nolting, J.M.; Massengill, R.; Baker, J.; Workman, J.D.; Slemons, R.D. Influenza A virus surveillance in waterfowl in Missouri, USA, 2005-2013. Avian Dis. 2015, 59, 303-308. [CrossRef]

34. Diskin, E.R.; Friedman, K.; Krauss, S.; Nolting, J.M.; Poulson, R.L.; Slemons, R.D.; Stallknecht, D.E.; Webster, R.G.; Bowman, A.S. Subtype diversity of influenza A virus in North American waterfowl: A multidecade study. J. Virol. 2020, 94, e02022-19. [CrossRef] [PubMed] 
35. Lauterbach, S.E.; McBride, D.S.; Shirkey, B.T.; Nolting, J.M.; Bowman, A.S. Year round influenza A virus surveillance in mallards (Anas platyrhynchos) reveals genetic persistence during the undersampled spring season. Viruses 2020, 12, 632. [CrossRef] [PubMed]

36. Suarez, D.L.; Schultz-Cherry, S. Immunology of avian influenza virus: A review. Dev. Comp. Immunol. 2000, 24, 269-283. [CrossRef] 